\title{
Studies on the Influence of Seed Pelleting on Seed Yield and Quality in French Bean (Phaseolus vulgaris L.) cv. "Arka Anoop"
}

\author{
K. Chaya Devi*, P. Balakrishna and J. Chandraprakash \\ Department of Seed Science and Technology, University of Agricultural Sciences, \\ GKVK, Bangalore - 65, India \\ *Corresponding author
}

\begin{abstract}
A B S T R A C T
Keywords

French bean seeds, chemicals,

botanicals, pelleting, seed yield, seed quality.

Article Info

Accepted:

17 April 2017

Available Online:

10 May 2017

A field experiment was conducted during rabi, 2013 at Department of Horticulture, UAS, GKVK, Bangalore to understand the influence of seed pelleting on seed yield and quality of french bean cv. Arka Anoop. The experiment consists of eight treatments with seed pelleting viz., $\mathrm{T}_{1}$ (control), $\mathrm{T}_{2}$ (seed pelleting with clay + Gypsum (1:1), $\mathrm{T}_{3}$ (seed pelleting with clay +Neem leaf powder + Gypsum $(1: 1: 1), \mathrm{T}_{4}$ (seed pelleting with biofertilizers (Rhizobium)@30 g/kg), $\mathrm{T}_{5}$ (seed pelleting with $\mathrm{ZnSO}_{4} @ 3 \mathrm{~g} / \mathrm{kg}$ ), $\mathrm{T}_{6}$ (seed pelleting with Borax @ $3 \mathrm{~g} / \mathrm{kg}), \mathrm{T}_{7}$ (seed pelleting with Capton $(2.5 \mathrm{~g} / \mathrm{kg})+$ Imidacloprid $(2.5 \mathrm{~g} / \mathrm{kg})$ and $\mathrm{T}_{8}$ (seed pelleting with $\mathrm{ZnSO}_{4} @ 3 \mathrm{~g} / \mathrm{kg}+$ borax @ $3 \mathrm{~g} / \mathrm{kg}+$ Capton $(2.5 \mathrm{~g} / \mathrm{kg})+$ Imidacloprid $(2.5 \mathrm{~g} / \mathrm{kg})$ and laid out in RCBD design with three replications. The experimental results indicated the superiority of seed pelleting with $\mathrm{ZnSO}_{4} @ 3 \mathrm{~g} / \mathrm{kg}+$ borax@3g/kg + Capton $(2.5 \mathrm{~g} / \mathrm{kg})+$ Imidacloprid $(2.5 \mathrm{~g} / \mathrm{kg})$ as compared to all other treatments including unpelleted control. Data on seed yield and quality parameters such as number of seeds per pod (5.33), seed yield per plant (24.47g), seed yield per plot (513.8g), seed yield per hectare $(28.54 \mathrm{q})$, seed index $(36.39 \mathrm{~g})$, germination $(99.00 \%)$, root length $(22.83 \mathrm{~cm})$, shoot length $(12.36 \mathrm{~cm})$, root and shoot ratio $(0.540)$, seedling length $(35.20 \mathrm{~cm})$, seedling dry weight $(248.83 \mathrm{mg})$, seedling vigour index-I (3484), seedling vigour index-II (2463), lower electrical conductivity $\left(1.16 \mathrm{dScm}^{-1}\right), \mathrm{pH}$ of seed leachate (6.96) and total dehydrogenase activity (2.77) was maximum in seed pelleted with $\mathrm{ZnSO}_{4}$ @3g/kg + borax @3g/kg + Capton (2.5g/kg) + Imidacloprid (2.5g/kg) compared to control.
\end{abstract}

\section{Introduction}

French bean (Phaseolus vulgaris L.) is one of the most important vegetable pulse crop which is native to new world probably Central Mexico which belongs to family Fabaceae is a nutritious vegetable consumed as tender pods, shelled beans and dry beans. It has many synonyms like Snap bean, Kidney bean, Haricot bean and also called Rajmash in Hindi. It possess some medicinal properties which is useful in controlling diabetics and certain cardiac problems and it is a good natural cure for bladder burn. It has both carminative and reparative properties against constipation and diarrhoea (Duke, 1981).

Seed pelleting is the process of enclosing a seed with small quantity of inert material just large enough to produce globular unit of standard size to facilitate precision planting. The inherent material creates natural water 
holding media and provides small amount of nutrients to young seedlings. It also reduces the problem of thinning, gap filling and chemicals required in low quantity. Keeping in view the experiment is followed to know the outcome of the seed pelleting on seed yield and quality.

\section{Materials and Methods}

The experiment was conducted during rabi, 2013 at Department of Horticulture, University of Agricultural Sciences, GKVK, Bangalore. The experiment was laid out in randomized complete block design with eight treatments replicated thrice. The french bean seeds were pelleted with $\mathrm{T}_{1}$ (control), $\mathrm{T}_{2}$ (seed pelleting with clay + Gypsum $(1: 1), \mathrm{T}_{3}$ (seed pelleting with clay + Neem leaf powder + Gypsum (1:1:1), $\mathrm{T}_{4}$ (seed pelleting with biofertilizers (Rhizobium) @ $30 \mathrm{~g} / \mathrm{kg}$ ), $\mathrm{T}_{5}$ (seed pelleting with $\mathrm{ZnSO}_{4} @ 3 \mathrm{~g} / \mathrm{kg}$ ), $\mathrm{T}_{6}$ (seed pelleting with Borax @ $3 \mathrm{~g} / \mathrm{kg}$ ), $\mathrm{T}_{7}$ (seed pelleting with Capton $(2.5 \mathrm{~g} / \mathrm{kg})+$ Imidacloprid $(2.5 \mathrm{~g} / \mathrm{kg})$ and $\mathrm{T}_{8}$ (seed pelleting with $\mathrm{ZnSO}_{4} @ 3 \mathrm{~g} / \mathrm{kg}+$ borax @ $3 \mathrm{~g} / \mathrm{kg}+$ Capton $(2.5 \mathrm{~g} / \mathrm{kg})+$ Imidacloprid $(2.5 \mathrm{~g} / \mathrm{kg})$. The spacing of $30 \times 10 \mathrm{~cm}$ was followed with net plot size of $1.2 \times 1.5 \mathrm{~m}$. All the recommended cultural practices for French bean crop were followed. Five normal plants were selected randomly in the net plot area and tagged with a label in each treatment to record the observations.

The observation on number of seeds per pod, seed yield per plant, seed yield per plot, seed yield per hectare, seed index, germination, root length, shoot length, root and shoot ratio, mean seedling length, seedling dry weight, seedling vigour index-I, seedling vigour index-II, lower electrical conductivity, $\mathrm{pH}$ of seed leachate, and total dehydrogenase activity was recorded. The data was statistically analysed and the results are presented in table 1, 2 and 3.

\section{Results and Discussion}

The results on seed yield and quality as influenced by the seed pelleting is significant and discussed here with the seeds pelleted with different chemicals and botanicals recorded significantly higher number of seeds per pod, seed yield per plant, seed yield per plot, seed yield per hectare, seed index, germination, root length, shoot length, root and shoot ratio, seedling length, seedling dry weight, seedling vigour index-I, seedling vigour index-II, lower electrical conductivity, $\mathrm{pH}$ of seed leachate, and total dehydrogenase activity. Among the different pelleting treatments, seeds pelleted with $\mathrm{T}_{8}$ (seed pelleting with $\mathrm{ZnSO}_{4} @ 3 \mathrm{~g} / \mathrm{kg}+$ borax @ $3 \mathrm{~g} / \mathrm{kg}+$ Capton $(2.5 \mathrm{~g} / \mathrm{kg})+$ Imidacloprid $(2.5 \mathrm{~g} / \mathrm{kg})$ recorded significantly highest number of seeds per pod (5.33), seed yield per plant $(24.47 \mathrm{~g})$, seed yield per plot $(513.8 \mathrm{~g})$ and seed yield per hectare (28.54q) respectively over control which was due to the involvement in sugar synthesis and its efficient translocation for seed formation and development (Berger, 1949; Shkolnik and Abdurashitov, 1958). Similar results with boron were reported by Srimathi et al., (2001) and Supreeta Angadi (2004) in soybean and Masuthi (2005) in cowpea and Angumuthu (1991) in miner millets. Zinc element is involved in auxin metabolism, plays a pivotal role in seed size and development. The second phase of seed development requires adequate amount of zinc dependent upon auxin for seed development. Hence, in the present study also maximum seed yield and yield traits have been noticed with $\mathrm{ZnSO}_{4}$ seed pelleting treatments. Among pelleting treatments $\mathrm{ZnSO}_{4} @ 3 \mathrm{~g} / \mathrm{kg}+$ borax @3g/kg + Capton $(2.5 \mathrm{~g} / \mathrm{kg})+$ Imidacloprid $(2.5 \mathrm{~g} / \mathrm{kg})$ recorded highest seed index $(36.39 \mathrm{~g})$, germination $(99.00 \%)$, root length $(22.83 \mathrm{~cm})$, shoot length $(12.36 \mathrm{~cm})$, root and shoot ratio (0.540), mean seedling length $(35.20 \mathrm{~cm})$ compared to control. 
Table.1 Influence of seed pelleting on seed yield parameters in French bean (Phaseolus vulgaris) cv. Arka Anoop during rabi, 2013

\begin{tabular}{|c|c|c|c|c|}
\hline Treatments & $\begin{array}{c}\text { Number of seeds } \\
\text { per pod }\end{array}$ & $\begin{array}{c}\text { Seed yield per } \\
\text { plant }(\mathbf{g})\end{array}$ & $\begin{array}{c}\text { Seed yield per plot } \\
\text { (g) }\end{array}$ & $\begin{array}{c}\text { Seed yield } \\
\text { per hectare } \\
(\mathbf{q})\end{array}$ \\
\hline $\mathbf{T}_{\mathbf{1}}$ & 3.33 & 17.42 & 366.0 & 20.32 \\
\hline $\mathbf{T}_{\mathbf{2}}$ & 3.66 & 18.12 & 380.5 & 21.14 \\
\hline $\mathbf{T}_{\mathbf{3}}$ & 4.00 & 19.13 & 401.7 & 22.31 \\
\hline $\mathbf{T}_{\mathbf{4}}$ & 4.00 & 20.25 & 405.5 & 22.50 \\
\hline $\mathbf{T}_{\mathbf{5}}$ & 5.00 & 22.15 & 465.1 & 25.84 \\
\hline $\mathbf{T}_{\mathbf{6}}$ & 4.33 & 21.43 & 450.2 & 25.01 \\
\hline $\mathbf{T}_{\mathbf{7}}$ & 5.00 & 22.95 & 481.1 & 26.72 \\
\hline $\mathbf{T}_{\mathbf{8}}$ & 5.33 & 24.47 & 513.8 & 28.54 \\
\hline Grand mean & 4.33 & 20.74 & 433.0 & 24.04 \\
\hline S. Em $\mathbf{E}$ & 0.19 & 0.13 & 2.69 & 0.13 \\
\hline C.D (P=0.05) & 0.58 & 0.41 & 8.61 & 0.41 \\
\hline CV (\%) & 7.76 & 9.15 & 10.98 & 11.28 \\
\hline
\end{tabular}


Table.2 Influence of seed pelleting on seed quality parameters in French bean (Phaseolus vulgaris) cv. Arka Anoop during rabi, 2013

\begin{tabular}{|c|c|c|c|c|c|c|}
\hline Treatments & $\begin{array}{c}\text { Seed } \\
\text { Index (g) }\end{array}$ & $\begin{array}{c}\text { Germination } \\
(\%)\end{array}$ & $\begin{array}{c}\text { Root } \\
\text { length } \\
(\mathrm{cm})\end{array}$ & $\begin{array}{c}\text { Shoot } \\
\text { length }(\mathrm{cm})\end{array}$ & $\begin{array}{l}\text { Shoot and } \\
\text { Root ratio }\end{array}$ & Seedling length $(\mathrm{cm})$ \\
\hline $\mathbf{T}_{1}$ & 29.04 & 95.66 & 16.50 & 7.73 & 0.470 & 24.23 \\
\hline $\mathbf{T}_{2}$ & 30.06 & 96.33 & 16.86 & 8.23 & 0.486 & 25.10 \\
\hline $\mathbf{T}_{\mathbf{3}}$ & 30.65 & 97.00 & 17.56 & 8.70 & 0.496 & 26.26 \\
\hline $\mathbf{T}_{4}$ & 32.84 & 97.66 & 18.30 & 9.10 & 0.496 & 27.40 \\
\hline $\mathbf{T}_{5}$ & 34.57 & 98.66 & 20.56 & 10.46 & 0.510 & 31.03 \\
\hline $\mathbf{T}_{6}$ & 33.36 & 98.33 & 19.13 & 9.60 & 0.503 & 28.73 \\
\hline $\mathbf{T}_{7}$ & 35.30 & 98.66 & 21.80 & 11.26 & 0.516 & 33.06 \\
\hline $\mathbf{T}_{8}$ & 36.39 & 99.00 & 22.83 & 12.36 & 0.540 & 35.20 \\
\hline Grand mean & 32.77 & 97.66 & 19.19 & 9.68 & 0.502 & 28.87 \\
\hline S. Em \pm & 0.32 & 0.30 & 0.23 & 0.19 & 0.009 & 0.34 \\
\hline C.D $(P=0.05)$ & 0.98 & 0.93 & 0.70 & 0.60 & 0.029 & 1.04 \\
\hline CV (\%) & 1.71 & 0.54 & 2.08 & 3.54 & 3.335 & 2.06 \\
\hline
\end{tabular}


Table.3 Influence of seed pelleting on seed quality parameters in French bean (Phaseolus vulgaris) cv. Arka Anoop during rabi, 2013

\begin{tabular}{|c|c|c|c|c|c|c|}
\hline Treatments & $\begin{array}{l}\text { Seedling dry } \\
\text { weight (mg) }\end{array}$ & $\begin{array}{c}\text { Seedling } \\
\text { vigour Index-I }\end{array}$ & $\begin{array}{l}\text { Seedling } \\
\text { vigour } \\
\text { Index-II } \\
\end{array}$ & $\begin{array}{c}\text { Electrical } \\
\text { Conductivity } \\
\left(\mathbf{d S m}^{-1}\right) \\
\end{array}$ & $\begin{array}{l}\text { pH of seed } \\
\text { leachate }\end{array}$ & $\begin{array}{c}\text { Total Dehydrogenase } \\
\text { Activity }\end{array}$ \\
\hline $\mathbf{T}_{1}$ & 173.20 & 2318 & 1657 & 1.53 & 6.56 & 2.65 \\
\hline $\mathbf{T}_{2}$ & 181.50 & 2418 & 1748 & 1.48 & 6.60 & 2.67 \\
\hline $\mathbf{T}_{3}$ & 191.66 & 2548 & 1859 & 1.43 & 6.70 & 2.68 \\
\hline $\mathbf{T}_{4}$ & 200.63 & 2676 & 1959 & 1.39 & 6.76 & 2.70 \\
\hline $\mathbf{T}_{5}$ & 222.06 & 3062 & 2191 & 1.28 & 6.86 & 2.75 \\
\hline $\mathbf{T}_{6}$ & 210.03 & 2826 & 2065 & 1.33 & 6.80 & 2.72 \\
\hline $\mathbf{T}_{7}$ & 236.60 & 3262 & 2334 & 1.21 & 6.90 & 2.76 \\
\hline $\mathbf{T}_{8}$ & 248.83 & 3484 & 2463 & 1.16 & 6.96 & 2.77 \\
\hline Grand mean & 208.06 & 2824 & 2034 & 1.35 & 6.77 & 2.71 \\
\hline S. Em \pm & 2.40 & 38.80 & 270.4 & 0.01 & 0.02 & 0.003 \\
\hline C.D $(P=0.05)$ & 7.30 & 117.69 & 820.4 & 0.04 & 0.07 & 0.009 \\
\hline CV (\%) & 2.00 & 2.37 & 2.30 & 1.75 & 0.64 & 0.204 \\
\hline
\end{tabular}


The higher seed quality parameters are positively related to seed development which is reflected through size of seed and test weight which in turn is dependent on efficient synthesis, translocation and accumulation of food metabolites such as proteins in leguminous crops. Hence, higher seed quality parameters observed with pelleting treatment ZnSO4@3g/kg + borax@3g/kg + Capton $(2.5 \mathrm{~g} / \mathrm{kg})+$ Imidacloprid $(2.5 \mathrm{~g} / \mathrm{kg})$ may be due to their efficient role in sinksource relationship. Seed with higher initial capital food reserves always showed higher and rapid germination which is also true in the present study. Similar results were also reported by Balaji (1990), Supreeta angadi (2004) in soybean and Masuthi (2005) in cowpea.

Among pelleting treatments $\mathrm{ZnSO} 4$ @ $3 \mathrm{~g} / \mathrm{kg}$ + borax @ 3g/kg + Capton $(2.5 \mathrm{~g} / \mathrm{kg})$ + Imidacloprid $(2.5 \mathrm{~g} / \mathrm{kg})$ pelleted seeds recorded highest seedling dry weight (248.83mg), seedling vigour index-I (3484), seedling vigour index-II (2463), lower electrical conductivity $\left(1.16 \mathrm{dScm}^{-1}\right), \mathrm{pH}$ of seed leachate (6.96) and total dehydrogenase activity (2.77) over control.

The higher seedling vigour parameters which were recorded, may be due to the fact that well developed high quality seeds with higher test weight shall have higher germination potential and seedlings growth will be vigorous with higher root and shoot length. The vigour index being the product of germination and seedling length, it is also higher with these pelleted seed treatment in the present study. Similar beneficial influence of seed pelleting treatments with ZnSO4 @ $3 \mathrm{~g} / \mathrm{kg}+$ borax @ 3g/kg + Capton $(2.5 \mathrm{~g} / \mathrm{kg})+$ Imidacloprid $(2.5 \mathrm{~g} / \mathrm{kg})$ may be ascribed to their role in enhanced metabolic activity, earliness in germination, cell division and elongation leading to production of increased seedling growth in soybean (Balaji, 1990; Supreeta Angadi, 2004; Rathinavel et al.,
2000; Masuthi, 2005). As zinc is the constituent of several dehydrogenase enzyme and an activator of other enzymes, which might have triggered the germination and seedling growth (Jeyabal et al., 1999). Hence the study can be concluded seed pelleted with (T8) $\mathrm{ZnSO} 4 @ 3 \mathrm{~g} / \mathrm{kg}+$ borax @ 3g/kg + Capton $(2.5 \mathrm{~g} / \mathrm{kg})+$ Imidacloprid $(2.5 \mathrm{~g} / \mathrm{kg})$ could be recommended for the French bean cultivation to harvest higher seed yield and seed quality.

\section{References}

Angumuthu, R., 1991, Studies on seed pelleting, physiological maturity, sowing quality and storage of small millets. M.Sc. (Agri.) Thesis, Tamilnadu Agric. Univ., Coimbatore.

Balaji, D.S., 1990, Studies on the seed soil relationship in certain crops paddy, greengram, soybean, redgram, sunflower, groundnut and cotton. $M$. Sc. (Agri.) Thesis, Tamil Nadu Agric. Univ., Coimbatore, India.

Berger, K.C., 1949. Boron in soils and crops. Adv. in Agron., 1: 321-351.

Duke, J. A., 1981, Handbook of legumes of world economic importance. New York, USA/ London, UK: pp, 195-200.

Jeyabal, A. and Kuppuswamy, G., 1999, Effect of nutrient coating on seedling vigour, nutrient uptake and yield of rice (Oryza sativa L.). Indian J. Agron., 44 (2): 304-309.

Masuthi, D. A., 2005, Effect of phosphorous, zinc and boron on fruit set, seed yield and quality of vegetable cowpea (Vigna anguiculata (L.). M.Sc. (Agri) Thesis, Univ. Agric. Sci., Dharwad, Karnataka (India).

Rathinavel, K. and Dharmalingam, C., 1999, Effect of seed pelleting on elite seedling production in cotton $\mathrm{cv}$. MCU7 (Gossypium hirsutum L.). Crop Res., 18 (1): 137- 141. 
Shkolnik and Abdurashitov, S.A., 1958, Influence of micro-elements on synthesis and translocation of carbohydrates. Pl. Phy., USSR, 5 (5): 393-399.

Srimathi, P., Sastri, G. and Malarkodi, K., 2001, Influence of seed pelleting on crop establish of soybean. Nat.Symp. on

Pulse and Seeds held at Coimbatore, pp. 107.

Supreetha Angadi, 2004, Effect of seed pelleting on field performance and storability in soybean (Glycine max (L.) Merrill). M.Sc. (Agri) Thesis, Univ. of Agric. Sci., Dharwad, Karnataka, India.

\section{How to cite this article:}

K. Chaya Devi, P. Balakrishna and J. Chandraprakash. 2017. Studies on the Influence of Seed Pelleting on Seed Yield and Quality in French Bean (Phaseolus vulgaris L.) cv. "Arka Anoop". Int.J.Curr.Microbiol.App.Sci. 6(5): 1912-1918. doi: https://doi.org/10.20546/ijcmas.2017.605.212 